\title{
Overcoming fragmentation in health care: chronic care in Austria, Germany and the Netherlands
}

\author{
ELLEN NOLTE* \\ Director, Health and Healthcare Research programme, RAND Europe, Cambridge, UK \\ CÉCILE KNAI \\ Lecturer in European Health Policy, Faculty of Health Services Research and Policy, London School of Hygiene and \\ Tropical Medicine, London, UK
}

MARIA HOFMARCHER

Director Health and Care, European Centre for Social Welfare Policy and Research, Vienna, Austria ANNALIJN CONKLIN

Analyst, Health and Healthcare Research programme, RAND Europe, Cambridge, UK

ANTJE ERLER

Senior Researcher, Institute of General Practice, Johann Wolfgang Goethe University Frankfurt, Germany ARIANNE ELISSEN

Research Fellow, Department of Health Services Research, CAPHRI School for Public Health and Primary Care, Maastricht University, The Netherlands

MARIA FLAMM

Research Fellow, Institute of General Practice, Paracelsus Medical University Salzburg, Austria BRIGIT FULLERTON

Research Fellow, Institute of General Practice, Johann Wolfgang Goethe University Frankfurt, Germany ANDREAS SÖNNICHSEN

Professor of Medicine, Institute of General Practice, Paracelsus Medical University Salzburg, Austria HUBERTUS J. M. VRIJHOEF

Professor, TRANZO Scientific Center for Care and Welfare, Tilburg University, The Netherlands

\begin{abstract}
The growing recognition of care fragmentation is causing many countries to explore new approaches to healthcare delivery that can bridge the boundaries between professions, providers and institutions and so better support the rising number of people with chronic health problems. This paper examines the role of the regulatory, funding and organisational context for the development and implementation of approaches to chronic care, using examples from Austria, Germany and the Netherlands. We find that the three countries have implemented a range of policies and approaches to achieve better coordination within and across the primary and secondary care interface and so better meet the needs of patients with chronic conditions. This has involved changes to the regulatory framework to support more coordinated approaches to care (Austria, Germany), coupled with financial incentives
\end{abstract}

*Correspondence to: Dr Ellen Nolte, RAND Europe, Westbrook Centre, Milton Road, Cambridge CB4 1YG, UK. E-mail: enolte@rand.org 
(Austria, Germany) or changes in payment systems (the Netherlands). What is common to the three countries is the comparative 'novelty' of policies and approaches aimed at fostering coordinated care; however, the evidence of their impact remains unclear.

\section{Introduction}

The rising number of people with chronic conditions presents challenges for all health systems. In the European Union, in 2006, between $20 \%$ to over $40 \%$ of the population aged 15 years and over reported a long-standing health problem and one-fourth currently receives medical long-term treatment (TNS Opinion and Social, 2007). The complex nature of many chronic health problems requires a delivery system that involves coordinated inputs from a wide range of health professionals over an extended period of time and that places patients at the centre as co-producers of care to optimise health outcomes (Nolte and McKee, 2008a, 2008b). Yet, service delivery has developed in ways that have tended to fragment care, both within and between sectors, through, for example, structural and financial barriers dividing providers at the primary/secondary care and at the healthcare and social care interface (Glasby et al., 2006).

The growing recognition of this fragmentation is causing many countries to explore new approaches to healthcare delivery that can bridge the boundaries between professions, providers and institutions and so provide appropriate support to patients with long-standing health problems. Key elements suggested to address fragmentation include improved collection and sharing of information, moving care into the community and aligning payment schemes to incentivise care coordination and enhance integration of provision of services (Hofmarcher et al., 2007). However, countries vary in their attempts to do so and approaches that are being implemented reflect the characteristics of individual health systems as they relate to the relationships between, and responsibilities of, different stakeholders in the regulation, funding and delivery of health care (Nolte et al., 2008).

This paper discusses some of the key approaches to overcoming fragmentation in health care, with a particular focus on the role of the regulatory, funding and organisational context for the development and implementation of approaches to chronic care. We illustrate these approaches with examples from Austria, Germany and the Netherlands.

Our analysis is based on a review of the published and grey literature, complemented by data collected within the DISMEVAL project (Developing and validating DISease Management EVALuation methods for European healthcare systems), using a common data collection template which is described in detail elsewhere (RAND Europe and London School of Hygiene and Tropical Medicine, 2011).

In order to contextualise chronic care development in each country, we provide a concise overview of selected features of the country's health systems. We describe 
the key regulatory and policy measures making possible current chronic care strategies, highlighting some of the main approaches to overcoming fragmentation in chronic care and reviewing the documented evidence of their impact.

\section{Background on chronic care in Austria, Germany and the Netherlands}

The implementation of chronic care policies in Austria, Germany and the Netherlands has to be understood in the overall context of healthcare governance and organisation. The three healthcare systems are principally based on the Bismarckian model of statutory health insurance (SHI), characterised by a universal, mandatory insurance scheme with responsibility for the healthcare system shared by government (central and state governments in Austria and Germany) and corporatist actors. More recently, the three systems have followed different paths, in particular with regard to the introduction of market elements into the system. In brief, in 1993, Germany introduced free choice of SHI (Busse and Riesberg, 2004), whereas the Netherlands moved to a mandatory, regulated private insurance system with competing private insurance funds in 2006 (Schäfer et al., 2010). In Austria, competition among health insurers, although discussed, has so far not been pursued (Hofmarcher and Rack, 2006). In terms of the provision of health care, the Netherlands is unique among SHI systems in western Europe in that general practitioners (GPs) act as gatekeepers to specialist care, a characteristic feature maintained after the 2006 reform (Schäfer et al., 2010). In contrast, Austria and Germany principally allow for free choice of office-based generalist and specialist care providers outside hospital (Busse and Riesberg, 2004; Hofmarcher and Rack, 2006). Table 1 provides an overview of selected characteristics of healthcare governance and provision in each country.

\section{The evolution of chronic care policies}

Care fragmentation, particularly at the boundary between primary and secondary care, has been a main concern in all three countries, and it has prompted a series of various regulatory measures and activities (Table 2). However, the pace, breadth and depth with which relevant initiatives and policies have been implemented have varied.

Thus, in Germany, provisions to support more integrated models of care were introduced as early as 1993, subsequently strengthened by the 2000 SHI Reform Act and the 2004 SHI Modernisation Act, which removed certain legal and financial obstacles towards better integration (Busse and Riesberg, 2004). In parallel, in 2002, the government introduced structured care programmes for those with chronic disease, frequently referred to as 'disease management programmes' (DMPs), in an explicit effort to provide insurers and providers with incentives to encourage evidence-based chronic care (Siering, 2008). Defined as 
Table 1. Selected features of healthcare systems in Austria, Germany and the Netherlands

\begin{tabular}{|c|c|c|c|}
\hline & Austria & Germany & The Netherlands \\
\hline \multicolumn{4}{|l|}{ Health expenditure (2008) } \\
\hline$\%$ GDP & 10.5 & 10.5 & 9.9 \\
\hline Per capita expenditure (US\$ PPP) & 3970 & 3737 & 4063 \\
\hline \multirow[t]{4}{*}{ Main sources of financing (2008) } & SHI: $44.1 \%$ & SHI: $67.9 \%$ & "SHI: $70.2 \%$ \\
\hline & Taxation: $32.8 \%$ & Taxation: $8.8 \%$ & Taxation: $5.1 \%$ \\
\hline & OOP: $15.1 \%$ & OOP: $13.0 \%$ & OOP: $5.7 \%$ \\
\hline & VHI: $4.5 \%$ & VHI: $9.5 \%$ & VHI: $5.6 \%$ \\
\hline \multicolumn{4}{|l|}{ Governance of the public health system } \\
\hline Principle responsibilities & $\begin{array}{l}\text { Shared by central government, } \\
\text { nine state governments and } \\
\text { corporatist actors; responsibility } \\
\text { for hospital sector mainly with the } \\
\text { federal states }\end{array}$ & $\begin{array}{l}\text { Shared by central government, } 16 \\
\text { state governments and corporatist } \\
\text { actors; responsibility for hospital } \\
\text { sector mainly with the federal } \\
\text { states }\end{array}$ & $\begin{array}{l}\text { Shared by federal and local } \\
\text { authorities and corporatist actors }\end{array}$ \\
\hline $\begin{array}{l}\text { Main supervisory/regulatory body } \\
\text { independent of government (year } \\
\text { established) }\end{array}$ & $\begin{array}{l}\text { Federal Health Agency } \\
\text { (Bundesgesundheitsagentur, 2005); } \\
\text { separate legal entity responsible for } \\
\text { developing the framework for } \\
\text { planning health service provision } \\
\text { in all sectors, management of the } \\
\text { interface between sectors; } \\
\text { development of performance- } \\
\text { orientated reimbursement systems } \\
\text { in all healthcare sectors }\end{array}$ & $\begin{array}{l}\text { Federal Joint Committee } \\
\text { (Gemeinsamer Bundesausschuss, } \\
\text { G-BA, 2004); decision-making } \\
\text { body in SHI system; sets legal } \\
\text { framework for healthcare } \\
\text { provision, issues binding } \\
\text { directives, develops } \\
\text { recommendations for DMPs, } \\
\text { develops quality assurance } \\
\text { measures for ambulatory, hospital } \\
\text { and integrated care }\end{array}$ & $\begin{array}{l}\text { Dutch Health Care Authority } \\
\text { (Nederlandse Zorgautoriteit, NZa, } \\
\text { 2006); responsible for monitoring } \\
\text { and administering the markets for } \\
\text { health care provision, health } \\
\text { insurance and the purchasing of } \\
\text { health care; oversees the lawful } \\
\text { implementation of the Health } \\
\text { Insurance Act and Exceptional } \\
\text { Medical Expenses Act }\end{array}$ \\
\hline
\end{tabular}


Principles of healthcare provision outside hospital

Provision of primary/generalist and

specialist care outside hospital

Choice of provider in primary/

ambulatory care

GP gatekeeping

Payment of physicians in primary/ ambulatory care

Payment of hospitals
Office-based primary and specialist care physicians; outpatient clinics Yes

No

Blended system of fee-for-service with capitated element for basic services; determined by payment schemes based on public services or private law and supplemented

by bonuses defined by the state

Performance-oriented hospital

financing system (LKF; 1997)
Office-based primary and specialist care physicians

Yes

Voluntary ('GP contracts’)

Combination of capitation and feefor service based on centrally negotiated 'uniform value scale'

(EBM) by the Federal Association of SHI physicians and the National Association of SHI Funds

G-DRG (phased in from 2003)

\section{GPs in group practices}

Yes; registration with GP required

Yes; access to specialist care upon referral only

Combination of capitation and feefor-service; maximum remuneration fees for GPs negotiated between National Association of GPs, Health

Insurers Netherlands and Ministry of Health, Welfare and Sport

Diagnosis and treatment combinations (DBCs; 2005)

PPP, purchasing power parity; SHI, statutory health insurance; OOP, out-of-pocket payment; VHI, voluntary health insurance; DBCs, Diagnosis and treatment combinations; DMPs, disease management programmes; EBM, Einheitlicher Bewertungsmassstab; GPs, general practitioners; LKF, Leistungsorientierte Krankenanstaltenfinanzierung; G-DRG, German diagnosis-related groups.

Sources: Busse and Riesberg (2004); Ettelt et al. (2006); Hofmarcher and Rack (2006); OECD (2010); Schäfer et al. (2010)

Notes: *According to figures from the Dutch statistical office, in 2009, SHI accounted for $68 \%$ of GDP and taxation for $13 \%$, with the remainder including OOP $(\sim 9 \%)$ and VHI (4\%) (Centraal Bureau voor de Statistiek, 2009). 
Table 2. Overview of the regulatory framework for chronic care policies and approaches implemented during the 2000s in Austria, Germany and the Netherlands

\begin{tabular}{lll}
\hline \hline Country $\quad$ Title of reform/regulation & Stated aim/s of reform/regulation
\end{tabular}

Austria 2005 Health Reform Act

Germany

$$
2000 \text { SHI Reform Act }
$$

2001 Risk Structure

Compensation Reform Act

2004 SHI Modernisation Act

2007 Act to Strengthen

Competition within SHI

2008 Long-term Care Reform

Act

2008 Act on the Advancement of Organisational Structures within SHI

Netherlands 2006 Health Insurance Act

2007 Social Support Act
Established state health funds (Landesgesundheitsfonds, 2006); created financial pool at state level (Reform pool) as a means to promote coordination of and cooperation between ambulatory and hospital care; established Federal Health Agency; introduced e-card and made provisions for planing and accordance of electronic patient record by introducing the Health Data Transmission Law (Gesundheitstelematikgesetz)

Commits to continue and develop further measures implemented with the 2005 reform including (among others) the integrated planning of health services across sectors; the implementation of needsand patient-centred pilot projects in ambulatory care and the strengthening and further development of the reform pool to support chronic care approaches Introduced right for physicians to establish group practices ('ambulatory care centres') as limited liability company

Introduced provisions for the development of integrated care structures between the ambulatory care and hospital sector; required SHI funds to set aside a defined amount pr member for primary prevention or health promotion activities Introduced, from 2002, structured care programmes for those with chronic disease (disease management programmes) into the German healthcare system Established Federal Joint Committee; strengthened integrated care and GP-centred care (through GP contracts); introduced medical care centres which provide care across several healthcare specialities within the ambulatory care sector Made health insurance mandatory for all and introduced the morbidity-adjusted risk compensation scheme with effect from 2009 Enabled delegation of selected medical tasks to nonmedical staff in the framework of pilot projects Further strengthened provisions for GP-centred care

Established single mandatory insurance system; introduced possibility of selective contracting with collectives to target care delivery to those with chronic conditions

Introduced provisions to enable chronically ill and/ or disabled people to live independently and participate in society 
Table 2. (Continued)

\begin{tabular}{lll}
\hline \hline Country & \multicolumn{1}{c}{ Title of reform/regulation } & \multicolumn{1}{c}{ Stated aim/s of reform/regulation } \\
\hline $\begin{array}{l}\text { 2009 Act for Allowances for } \\
\text { the Chronically Ill and }\end{array}$ & $\begin{array}{l}\text { Introduced entitlement for the chronically ill and } \\
\text { disabled persons to receive a fixed allowance to } \\
\text { compensate for excessive healthcare expenses } \\
\text { 2009 Amendment of the 1993 } \\
\text { Individual Health Care } \\
\text { Professions Act }\end{array}$ & $\begin{array}{l}\text { Facilitated use of nurses in the care of chronically ill } \\
\text { and elderly people, enabling clinical nurse specialists } \\
\text { with set qualifications to autonomously perform } \\
\text { common and minor medical procedures }\end{array}$ \\
\hline \hline
\end{tabular}

SHI: statutory health insurance; GP, general practitioner.

'the coordinated treatment and care of patients during the entire duration of a (chronic) disease across boundaries between providers and on the basis of scientific and up-to-date evidence' (Bundesversicherungsamt, 2011), DMPs became the predominant approach to chronic illness care in Germany. Subsequent reforms introduced additional measures to strengthen coordination within the ambulatory care sector, most notably the 2004 introduction of GP-centred care and of medical care centres or policlinics (Ettelt et al., 2006), and provisions to enable the use of non-medical staff in chronic illness care from 2008 (Fullerton et al., 2011).

The Netherlands, in the 1990s, saw the introduction of the concept of shared care, based on the principle of cooperation and coordination between generalist and specialist caregivers with shared overall responsibility (Linden, 2000). Although spreading rapidly throughout the 1990s, lack of sufficient funding challenged their viability and sustainability. From the 2000s, disease management approaches received growing interest (Vrijhoef et al., 2001), but uptake remained limited (Steuten $e t$ al., 2002), mainly because of a lack of a structured framework (Klein-Lankhorst and Spreeuwenberg, 2008). More recently, the 2006 health insurance reform, which granted insurers extended powers to negotiate with provider organisations, facilitated the development of new forms of service delivery and payment for more integrated care. This involved the initially diabetes-focused establishment of GP-formed 'care groups' who contract with health insurers on the basis of a 'bundled payment' for a defined package of diabetes care (Struijs et al., 2010). This was strengthened by the 2008 'Programmatic approach to chronic illness care' and proposals to generally fund chronic care through bundled payment schemes, accompanied by regulatory measures to strengthen the role of nurses in the care of the chronically ill (Table 2; Schäfer et al., 2010).

In Austria, activities to strengthen more integrated provision of care have been a more recent phenomenon, with the 2005 health reform contributing to the development of related approaches (Hofmarcher and Rack, 2006). It established, in 2006, the State Health Funds in each of Austria's nine federal states 
and created a financial pool at state level (Reform pool), which combines funds from SHI and regional governments to finance projects that coordinate healthcare delivery across sectors, in particular between ambulatory and hospital care. These 'reform pool projects' have formed the basis for the majority of current approaches to chronic care in Austria, most frequently disease management programmes. Other efforts have aimed, since 2007, to establish ambulatory care centres to enhance integration of service delivery, particularly for those with chronic illness (Eichwalder and Hofmarcher, 2008). This was part of a wider policy development including the conclusion of agreements between the medical profession and health insurance funds to establish group practices, and the 2008-2013 government programme that made improving patient access to ambulatory care services a priority as part of an overall move to increase the effectiveness and efficiency of integrated healthcare services in the Austrian healthcare system (Hofmarcher and Hawel, 2010).

\section{Approaches to chronic care}

The regulatory and policy measures facilitated the implementation of chronic care approaches. This section describes in more detail the key features of approaches pursued in each of the countries, focusing on commonalities and differences between countries. As indicated above, the overarching care model tends to be a form of disease management, whose main characteristics as they relate to funding mechanisms, distribution and uptake, alongside principles of provider and patient participation and the coordination process are summarised in Tables 3 and 4.

\subsection{A focus on single chronic conditions}

Most approaches pursued in all three countries tend to be disease-specific, with type 2 diabetes most typically targeted. The focus on diabetes is perhaps not surprising, given the disease and cost burden associated with this condition worldwide (Pomerleau et al., 2008). However, a focus on diabetes was also prompted by existing examples of care models that could be drawn upon. For example, in the Netherlands, the development of diabetes care groups was greatly informed by a care model developed in Maastricht, the Maastricht Transmural Diabetes Organisation, which originates from the 1990s (Klein-Lankhorst and Spreeuwenberg, 2008). In Austria, the diabetes DMP was modelled, in part, on the disease management programme for type 2 diabetes developed in Germany. Other diseases targeted include cardiovascular disease, chronic respiratory disease and breast cancer (Germany).

However, the focus on single diseases has been identified as a concern, given the often multiple health problems among people with chronic conditions. In an attempt to address this, regulation in Germany has mandated the development 
Table 3. Features of the principal approach to chronic care in Austria, Germany and the Netherlands: target population, funding, distribution and uptake

\begin{tabular}{|c|c|c|c|c|c|c|}
\hline Approach & Aim/general description & Target population & $\begin{array}{c}\text { Year } \\
\text { implemented }\end{array}$ & Funding & $\begin{array}{l}\text { Use of financial } \\
\text { incentives }\end{array}$ & Distribution and uptake \\
\hline \multicolumn{7}{|l|}{ Austria } \\
\hline $\begin{array}{l}\text { Diabetes DMP } \\
\text { (Therapie } \\
\text { Aktiv) }\end{array}$ & $\begin{array}{l}\text { To improve the quality } \\
\text { of life and extend life for } \\
\text { people with chronic } \\
\text { disease, to place the } \\
\text { patient at the centre of } \\
\text { care and to make } \\
\text { efficient use of } \\
\text { healthcare resources and } \\
\text { also reduce } \\
\text { hospitalisations }\end{array}$ & Type 2 diabetes & 2006 & $\begin{array}{l}\text { Regional SHI fund } \\
\text { and federal state } \\
\text { contribute } \sim 50 \% \\
\text { each; programme } \\
\text { development funded } \\
\text { by regional SHI funds }\end{array}$ & $\begin{array}{l}\text { DMP physicians: } \\
\text { patient sign-up and } \\
\text { quarterly fee for } \\
\text { treatment and } \\
\text { documentation }\end{array}$ & $\begin{array}{l}\text { Implemented in five of nine } \\
\text { states; two states operate } \\
\text { separate programmes, one of } \\
\text { which is to be integrated into } \\
\text { Therapie Aktiv } \\
\text { Approximately } 17,000 \\
\text { patients are enrolled in the } \\
\text { DMP across Austria } \\
\text { ( } \sim 4.3 \% \text { of all people with } \\
\text { type } 2 \text { diabetes) }\end{array}$ \\
\hline DMP & $\begin{array}{l}\text { Organisational approach } \\
\text { to medical care that } \\
\text { involves the coordinated } \\
\text { treatment and care of } \\
\text { patients with chronic } \\
\text { disease across boundaries } \\
\text { between individual } \\
\text { providers on the basis of } \\
\text { scientific and up-to-date } \\
\text { evidence }\end{array}$ & $\begin{array}{l}\text { Types } 1 \text { and } 2 \text { diabetes, } \\
\text { coronary (plus chronic } \\
\text { heart failure), breast } \\
\text { cancer, asthma/chronic } \\
\text { obstructive pulmonary } \\
\text { disease (COPD) (obesity } \\
\text { module in preparation) }\end{array}$ & 2003 & $\begin{array}{l}\text { Funded from usual } \\
\text { sources (SHI) }\end{array}$ & $\begin{array}{l}\text { DMP physicians: } \\
\text { additional payment } \\
\text { for documentation } \\
\text { and education } \\
\text { Patients: may be } \\
\text { exempted from } \\
\text { practice fee }\end{array}$ & $\begin{array}{l}\text { DMPs are offered by SHI } \\
\text { funds, with } \sim 2000 \text { DMPs } \\
\text { for each condition }(2010) \text {; } \\
\text { number of participating } \\
\text { physicians varies, } \sim 65 \% \text { of } \\
\text { GPs act as DMP physician } \\
\text { for type } 2 \text { diabetes } \\
\text { By the end 2010, a total of } \\
5.75 \text { million individuals were } \\
\text { enrolled in one or more } \\
\text { DMPs, from } 127,700 \text { in } \\
\text { breast cancer DMP to } \sim 3.4 \\
\text { million in type } 2 \text { diabetes } \\
\text { DMP (approximately two- } \\
\text { thirds of diagnosed diabetics } \\
\text { in the SHI system) }\end{array}$ \\
\hline
\end{tabular}


Table 3. (Continued)

\begin{tabular}{|c|c|c|c|c|c|c|}
\hline Approach & Aim/general description & Target population & $\begin{array}{c}\text { Year } \\
\text { implemented }\end{array}$ & Funding & $\begin{array}{l}\text { Use of financial } \\
\text { incentives }\end{array}$ & Distribution and uptake \\
\hline \multicolumn{7}{|l|}{ Netherlands } \\
\hline $\begin{array}{l}\text { Bundled } \\
\text { payment } \\
\text { contract ('care } \\
\text { group') }\end{array}$ & $\begin{array}{l}\text { To facilitate } \\
\text { multidisciplinary } \\
\text { cooperation through } \\
\text { the elimination of } \\
\text { existing financial } \\
\text { barriers between } \\
\text { providers and sectors } \\
\text { based on nationally } \\
\text { defined care standard } \\
\text { that encompasses } \\
\text { prevention, early } \\
\text { detection, treatment and } \\
\text { rehabilitation }\end{array}$ & $\begin{array}{l}\text { Type } 2 \text { diabetes, } \\
\text { vascular risk, chronic } \\
\text { obstructive pulmonary } \\
\text { disease, heart failure } \\
\text { (under development) }\end{array}$ & $\begin{array}{l}2007 \\
\text { (diabetes) }\end{array}$ & $\begin{array}{l}\text { Funded from usual } \\
\text { sources (mandatory } \\
\text { insurance) on the } \\
\text { basis of a bundled } \\
\text { payment contract }\end{array}$ & $\begin{array}{l}\text { Physicians: bundled } \\
\text { payment for defined } \\
\text { package of care } \\
\text { Insurer: to negotiate } \\
\text { low price for care } \\
\text { chain }\end{array}$ & $\begin{array}{l}\text { There were } 97 \text { care groups } \\
\text { in March } 2010 \text { holding a } \\
\text { bundled payment contract } \\
\text { with a health insurer, } \\
\text { mostly for diabetes care; } \\
\text { there are relatively few care } \\
\text { groups for the provision of } \\
\text { vascular risk management; } \\
\text { of } 55 \text { care groups surveyed } \\
\text { in early } 2010 \text {, two had a } \\
\text { bundled payment contract } \\
\text { in place for vascular risk } \\
\text { management, whereas } 17 \\
\text { were preparing to contract }\end{array}$ \\
\hline
\end{tabular}

DMP, disease management programme; SHI, statutory health insurance. 
Table 4. Features of the principal approach to chronic care in Austria, Germany and the Netherlands: participation, principles of care coordination and patient self-management support, use of information systems

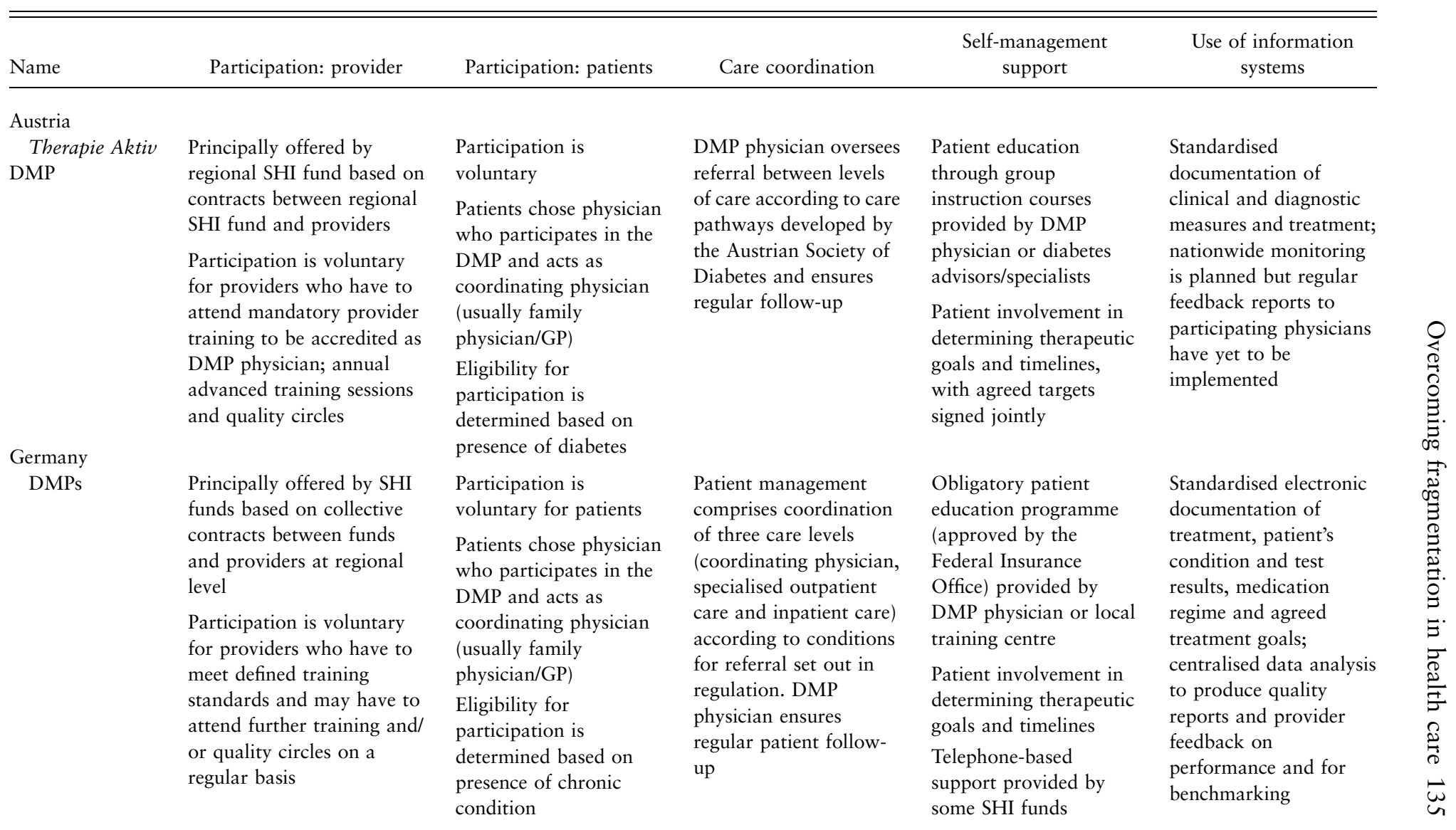


Table 4. (Continued)

\begin{tabular}{|c|c|c|c|c|c|}
\hline Name & Participation: provider & Participation: patients & Care coordination & $\begin{array}{l}\text { Self-management } \\
\text { support }\end{array}$ & $\begin{array}{l}\text { Use of information } \\
\text { systems }\end{array}$ \\
\hline $\begin{array}{l}\text { Netherlands } \\
\text { Bundled } \\
\text { payment } \\
\text { contract } \\
\text { ('care group') } \\
\text { (e.g. Heuvelland } \\
\text { diabetes care } \\
\text { group) }\end{array}$ & $\begin{array}{l}\text { Offered by care group who } \\
\text { contracts with health } \\
\text { insurers providing a } \\
\text { package of care defined by } \\
\text { national standards } \\
\text { Care group contracts with } \\
\text { and/or employs providers } \\
\text { (GPs, specialists, allied } \\
\text { staff); Heuvelland diabetes } \\
\text { care group brings together } \\
\text { all GPs in the region } \\
\text { (Maastricht) }\end{array}$ & $\begin{array}{l}\text { Patients join programme } \\
\text { through GP they are } \\
\text { registered with }\end{array}$ & $\begin{array}{l}\text { Patients are stratified } \\
\text { according to disease } \\
\text { severity into four } \\
\text { regular modules plus } \\
\text { two modules for } \\
\text { (complex) problems. GP } \\
\text { acts as central } \\
\text { coordinator, supported } \\
\text { by practice and } \\
\text { specialised nurses } \\
\text { responsible for care } \\
\text { management } \\
\text { GP oversees referral to } \\
\text { secondary care } \\
\text { according to defined } \\
\text { criteria and ensures } \\
\text { follow-up }\end{array}$ & $\begin{array}{l}\text { Regular check-ups } \\
\text { include education on } \\
\text { self-management by } \\
\text { practice nurses/ } \\
\text { specialised diabetes } \\
\text { nurses, depending on } \\
\text { the level of need; level of } \\
\text { need defines frequency } \\
\text { and duration of } \\
\text { consultations to be } \\
\text { conducted for } \\
\text { educational purposes }\end{array}$ & $\begin{array}{l}\text { Disease-specific } \\
\text { electronic patient record } \\
\text { ('MediX') contains } \\
\text { check-up and referrals } \\
\text { data within care } \\
\text { programme, allows for } \\
\text { information sharing and } \\
\text { automatisation of care } \\
\text { protocols, can be linked } \\
\text { to laboratory data and } \\
\text { functional } \\
\text { measurements }\end{array}$ \\
\hline
\end{tabular}

DMP, disease management programme; SHI, statutory health insurance; GP, general practitioner. 
of additional disease management modules for obesity and chronic heart failure to supplement existing DMPs (Siering, 2008). In the Netherlands, a framework to address overweight and obesity within the care group approach is being developed (Partnership Overweight Netherlands, 2009).

Approaches addressing a wider spectrum of needs, including those arising from multiple conditions, frequently centring on populations aged 65 years and above (here referred to as 'generalist' approaches) have also been introduced but have as yet remained geographically localised and/or restricted to pilot programmes.

\subsection{Conceptualisation of 'disease management' as a means to strengthen care coordination}

The overarching approach to strengthen care coordination is through some form of disease management although the content and scope of related approaches differs considerably between the three countries. Thus, the care groups in the Netherlands have been conceived as a multidisciplinary team approach with a physician ('director') overseeing the overall coordination between the various participating care providers, whereas patient management is, to great extent, delegated to nurses (Table 4). In contrast, in Germany and Austria, disease management has remained very much within the traditional structure of care provided by doctors within the ambulatory care sector, although following a strict protocol overseeing the patient management between levels of care, and in which non-medical staff (typically confined to practice assistants) play, if anything, a small role. Indeed, the use of non-medical staff such as specialised nurses or practice assistants Austria and Germany is a fairly recent phenomenon. Examples include GP contracts in Germany (Fullerton et al., 2011) or home care for patients with chronic heart failure in Salzburg, Austria (Arbeitskreis Vorsorgemedizin Salzburg, 2010). In Germany, services provided by nonmedical staff may include monitoring; the assessment of mental, physical or psychological problems; and coordination with other service providers. However, by law, all services must be assigned and performed under the supervision of the GP (Bewertungsausschuss nach $\S 87$ Abs. 1 Satz 1 SGB V, 2009).

\subsection{Incentivising the implementation of care coordination}

Several approaches use financial incentives, usually targeted at physicians although funders have also benefitted from additional (time limited) resources earmarked for care coordination and integration initiatives. For example, in Germany, to make disease management programmes an attractive option for the SHI funds, their introduction was linked to the risk structure compensation scheme (RSA). This provided SHI funds with a substantial financial incentive to offer DMPs as part of their portfolio of services and to motivate their members 
to take part in these programmes. This strategy had considerable success: by October 2009 SHI funds offered over 13,300 DMPs and a total of 5.5 million patients had signed up to at least one DMP (Bundesversicherungsamt, 2007). However, since 2009, following a reform of the RSA scheme with the introduction of a morbidity-adjusted RSA, the financial incentive for SHI funds has been reduced markedly, and numbers of patients signing up for DMPs have been stagnating since (Fullerton et al., 2011). Whether this stagnation reflects a saturation effect or is a consequence of the reduced financial incentive is as yet unclear.

At the same time, SHI funds were also given the possibility to designate financial resources, of a total of $1 \%$ of their income, for selective contracting with single providers or network of providers (Busse and Riesberg, 2004). The nature and scope of integrated care contracts has varied, with many focusing on the interface between acute hospital and rehabilitative care. By the end of 2008, approximately 6400 integrated care contracts had been concluded, covering $\sim 6 \%$ of all SHI insured. However, by the end of 2008 , when the financial incentive was concluded, less than half of these contracts had incorporated elements of intersectoral care (Sachverständigenrat zur Begutachtung der Entwicklung im Gesundheitswesen, 2009).

In the Netherlands, the bundled payment scheme is based on the principle of a care group (zorggroep), a legal entity that brings together providers (mostly GPs) in primary care. As the principal contractor, the care group enters into a contract with a health insurer to provide a package of care for a given condition according to a nationally developed care standard ('bundled payment contract'). The price for the package of care is negotiated between the provider care group and the insurance fund on the basis of the performance of the care group. Conceived as an 'experiment' in 2006, with 10 diabetes care groups receiving start-up funding for a period of 16 months and accompanying evaluation (Struijs et al., 2010), the government subsequently decided to roll-out this strategy nationally for the delivery of care for patients with diabetes, chronic obstructive pulmonary disease (COPD) or vascular risk (Vrijhoef, 2010). However, although diabetes contracts have achieved national coverage, the negotiation of a bundled payment for COPD and vascular risk management has remained a challenge (Van Til et al., 2010).

In Austria, as noted earlier, the reform pool made it possible to explicitly fund projects in integrated care, including disease management programmes described above, as well as a wide range of other approaches such as various forms of case management including managed discharge (Czypionka et al., 2008) or integrated care for stroke patients (Hofmarcher et al., 2007). However, implementation of reform pool activities has been uneven across states and related projects have been slow to take off partly because of a lack of financial incentives for physicians to participate in such projects. There has been limited federal oversight of the reform pool funds and projects, leading to duplication of efforts and a lack of scale-efficiency in some regions. The highest number of projects 
was funded in 2007 (23), at a cost of $€ 11$ million, but project activity fell subsequently. Of all funds available, only $16 \%$ had been put to use, but this varied greatly by region with over $30 \%$ used in Styria and only $1.5 \%$ in Tyrol (Czypionka and Röhrling, 2009).

\subsection{Encouraging uptake of programmes by patients and providers}

In all three countries, participation in the coordinated care approaches is voluntary for physicians and patients, and they are funded within the statutory system, thus making them principally available to all eligible patients. However, coverage is varied, in the case of diabetes care programmes ranging from some $4.3 \%$ of the population with type 2 diabetes in Austria (Österreichische Diabetes Gesellschaft, 2010) up to $\sim 60 \%$ in Germany (Schäfer et al., 2010a, 2010b). In the Netherlands, approximately two-thirds of an estimated 750,000 people with diabetes are covered by a bundled payment contract (Van Til et al., 2010).

The comparatively low uptake in Austria partly reflects variation in availability of relevant programmes across the different states, which, in turn, reflects variation in the participation rates of primary care physicians in such programmes (Therapie Aktiv Diabetes im Griff, 2011), ranging from an estimated $16 \%$ in Lower Austria and Vienna to 36\% in Salzburg (authors' estimates based on Habl and Bachner (2010)). Low participation may reflect physicians' resistance to the (perceived or real) additional administrative burden imposed by DMPs.

The administrative burden caused by documentation requirements was initially also a concern for physicians in Germany, following the introduction of DMPs (Siering, 2008); processes have since been simplified. In Germany, 65\% of GPs participate in the diabetes DMP, which may be explained by financial incentives offered to participating physicians. In the Netherlands, participation rates of GPs in structured care programmes are likely to be higher, with relevant incentives inherent in the structure of the bundled payment contract, offering considerable means to negotiate prices. Participation is estimated at 77\% of all GPs (Van Til et al., 2010) and is likely to increase further with government plans to move all care for diabetes (and other chronic conditions) to bundled payment contracts.

\section{What has the impact been?}

The preceding sections have demonstrated how all three countries reviewed here have implemented a range of policies and approaches to achieve better coordination within and across the primary and secondary care interface and so better meet the needs of patients with chronic conditions. This has involved changes to the regulatory framework to support more coordinated approaches to care (Austria, Germany), coupled with financial incentives (Austria, Germany) or changes in payment systems (the Netherlands). What is common to the three countries, as indeed in most other OECD countries (Hofmarcher et al., 2007), is the 
comparative 'novelty' of policies and approaches aimed at fostering coordinated care, and the evidence of their impact remains unclear.

In Germany, evidence from the statutory evaluation of diabetes DMPs points to improved quality of care for participating patients (Schäfer et al., 2010a, 2010b). The few existing controlled studies provide limited evidence of improved outcomes, such as quality of life (Ose et al., 2009) and mortality (Miksch et al., 2010; Stock et al., 2010) as well as reduced costs (Stock et al., 2010). However, the extent to which improved survival can indeed be attributed to the diabetes DMP remains uncertain (Miksch et al., 2010; Schäfer et al., 2010a, 2010b), with other studies failing to provide evidence of improved medical outcomes (Linder et al., 2011). In addition to methodological challenges, a major question remains as to whether disease-specific approaches such as the German DMPs are suited to meet the needs of the typical patient in primary care who frequently has multiple health problems with complex needs (Fullerton et al., 2011). More general approaches such as integrated care contracts or policlinics might potentially be better equipped to respond to more complex patient needs, yet evidence of their effect within the German healthcare system remains poorly understood because of lack of systematic evaluation.

In Austria, the phasing-in of DMPs was accompanied by evaluation in almost all federal states. For example, the diabetes DMP Therapie Aktiv, implemented in Salzburg, was evaluated using a cluster-randomised controlled trial. The evidence was mixed, however, with non-significant improvements in metabolic control, the main clinical outcome, although other measures (weight and cholesterol) improved significantly (Sönnichsen et al., 2010). Improved process measures were also observed for the diabetes DMPs implemented in Lower Austria, for example, demonstrating a reduction in hospital utilisation among those enrolled in a DMP pointing to the potential for cost savings although the overall evidence for DMPs to actually do so has remained inconclusive (Ruh et al., 2009).

In the Netherlands, findings from the evaluation of the first year of the 10 'experimental' diabetes care groups found wide variation in number and type of participants, the content of the packages of care covered, and price (between $€ 258$ and $€ 474$ per patient per year) (Struijs et al., 2010). Thus, contracts differed in the extent to which they offer additional services beyond the core package of care, such as smoking cessation guidance and/or foot care. Importantly, as the precise content of care is not clearly defined, there is a risk of 'double-billing' of selected care components, although the extent to which this is happening in practice is unknown. Evidence of impact on outcomes has remained inconclusive thus far. An expectation that diabetes care groups will, through improving the quality of (diabetes) care, lead to cost reductions could not be verified at 12-month follow-up; indeed, although costs might be saved due to reduced hospitalisations, they may at the same time increase because of 'intensification' of care for diabetic patients (Struijs et al., 2010), an observation that was also made for selected DMPs in Austria (Ruh et al., 2009). 


\section{Discussion}

In this paper, we have traced the evolution of chronic care in Austria, Germany and the Netherlands, all of which are principally financed from SHI. We find that countries have implemented a range of policies and approaches to overcome fragmentation in the healthcare system to achieve better coordination within and across the primary and secondary care interface and so better meet the needs of those with chronic conditions. A predominant model of care in the form of structured disease management has emerged in all three countries, although the evolution of these models has differed. Thus, in Germany, disease management was introduced in a top-down process, using a regulatory framework to ensure nationwide implementation (Siering, 2008). The Dutch model, although implemented nationwide upon government initiative, evolved from an experiment with a limited set of providers and informed by earlier experience of a delivery model developed in the 1990s (Klein-Lankhorst and Spreeuwenberg, 2008). In Austria, disease management programmes were made possible within the framework of a new financial instrument at the level of federal states, with states introducing such approaches broadly modelled on German DMPs. However, programmes have been slow to take off because projects require additional funds, and therefore disincentivising project approval (Hofmarcher et al., 2007).

Recent reforms in Austria have attempted to shift supply from inpatient to outpatient settings and improve patient access to ambulatory care services. However, these reforms have been restricted to physicians and are yet to take off in practice. Overall, this highlights the challenges experienced in Austria to arriving at an overarching strategic approach in a system that involves multiple actors in the negotiation of ambulatory care, including 21 SHI funds, the Federation of Austrian Social Security Institutions, the Austrian Medical Association and associations of other health professions (Hofmarcher and Rack, 2006). One area where the central government has taken a clear position is in efforts to promote a more integrated approach to planning, which is now being pursued towards coordinated supply across healthcare sectors.

In Germany, in contrast, while also involving multiple actors, negotiations relating to the ambulatory care sector are centralised at the national level (Busse and Riesberg, 2004), which may have facilitated the development of a national framework. However, it should be noted that the introduction of DMPs was strongly supported by SHI funds such as the general regional funds, which, because of their member profile, were disadvantaged by the RSA and their national association took a leading role in the promotion of the programmes. The government was also very supportive of swift implementation of DMPs and it took provisions to do so despite resistance from many stakeholders.

At the same time, although the creation of a strict national regulatory framework has been viewed as beneficial in ensuring that programmes meet appropriate standards, there have been concerns that this may limit the way in 
which this approach is able to address local need (Siering, 2008). The Dutch approach of 'incremental' implementation (Helderman et al., 2005), starting out with a select set of pilots experimenting with bundled payment and that are being evaluated for subsequent roll-out may be regarded as an approach that combines centrally defined requirements and local autonomy, although it should be noted that national roll-out was advocated by the government before evaluation findings were available.

Ham (2003) has highlighted how competing pressures on organisations that arise from policies initiated by healthcare reformers on one hand and established ways of delivery, on the other, are likely to result in a gap between policy intent and actual implementation (Ham, 2003). A critical role has to be played by professionals, who exert a large degree of control in healthcare organisations such as primary care practices and hospitals. Failure to engage them in the reform process is likely to hamper sustainable change. Indeed, as work on 'chains of care' in Sweden has demonstrated, approaches that engaged professionals, or were indeed initiated by professionals themselves, succeeded in developing improved interorganisational and interprofessional coordinated structures, whereas those initiated top-down by councils did not (Ahgren and Axelsson, 2007). However, a supportive policy environment was also found to be critical for success.

Fundamentally, it is, however, important to highlight that DMPs in Germany and Austria did not fundamentally alter (or indeed challenge) existing structures in the healthcare system. Services continue to be provided within the existing delivery structure, comprising family physicians, specialists in private practice and hospitals. The integration of non-medical health professionals into the care system, which has led to considerable improvements in chronic care elsewhere, has only recently been pursued, although remaining limited to certain settings. In Germany, although wider use of nurses was considered and supported by the German nurses association as a means to strengthen the role of nurse practitioners, other stakeholders, in particular family physicians and their associations, were concerned about introducing another layer of care as well as losing control over the provision of medical care. It is interesting to note, in this context, that the role of nurses in the Dutch care groups, although prominent, has been reduced somewhat compared to the model that informed their development (Klein-Lankhorst and Spreeuwenberg, 2008). Here, the specialist diabetes nurse acted as liaison between the hospital and primary care for all patients and indeed acted as consultant to the GP who was responsible for the management of diabetes patients with low intensity needs. In 2007, the model was transformed into the diabetes care group by the Regional General Practitioners Organization in Maastricht/Heuvelland region. Thus, professional resistance to change remains in a challenge in all systems.

Finally, one of the greatest challenges for the systems reviewed here remains the development of a system-wide model of care for patients with chronic disease. As noted earlier, disease-specific approaches such as disease management programmes are ill-suited to meet the needs of the typical patient in primary care 
who frequently has multiple health problems with complex needs (Nolte and McKee, 2008a, 2008b). The Dutch care groups, although disease-focused, are envisaged as multidisciplinary care teams and, through stratification of patients according to severity and required care intensity, may go some way to meeting the requirements of those with multiple health problems. However, more generalist approaches such as the integrated care contracts implemented in Germany are potentially better equipped to respond more complex patient needs, yet the evidence as to their effect within the German healthcare system remains poorly understood. There is a need for more systematic evaluation of new models of care as a means to inform the development of efficient and effective interventions to address the growing burden of chronic conditions in Europe and elsewhere.

\section{Acknowledgements}

This work was supported, in part, by the DISMEVAL project funded under the European Commission FP7 programme (Grant no. 223277). The authors further gratefully acknowledge the research assistance provided by Leslie Tarver.

\section{References}

Ahgren, B. and R. Axelsson (2007), 'Determinants of integrated health care development: chains of care in Sweden', International Journal of Health Planning and Management, 22: $145-157$.

Arbeitskreis Vorsorgemedizin Salzburg (2010), 'Kardiomobil - Heimbetreuung für Herzinsuffizienz-PatientInnen', http://www.avos.at/konzept/kardio.htm [20 December 2010].

Bewertungsausschuss nach $\S 87$ Abs. 1 Satz 1 SGB V (2009), 'Durchführungsempfehlung des Bewertungsausschusses nach $\S 87$ Abs. 1 Satz 1 SGB V in seiner 176. Sitzung am 17. März 2009 zur Finanzierung der Kostenpauschalen im Zusammenhang mit der Einführung delegierbarer Leistungen in das vertraglich vereinbarte Kapitel 40 des Einheitlichen Bewertungsmaßstabes (EBM) zum 1 April 2009', http://www.kbv.de/8157.html [30 December 2010].

Bundesversicherungsamt (2007), 'Zulassung der Disease Management Programme (DMP) durch das Bundesversicherungsamt (BVA)', http://www.bva.de/ [15 May 2008]

Bundesversicherungsamt (2011), 'Zulassung der Disease Management Programme (DMP) durch das Bundesversicherungsamt (BVA)', http://www.bundesversicherungsamt.de/ cln_108/nn_1046154/DE/DMP/dmp__inhalt.html [12 August 2011].

Busse, R. and A. Riesberg (2004), Health Care Systems in Transition: Germany, Copenhagen: WHO Regional Office for Europe on behalf of the European Observatory on Health Systems and Policies.

Centraal Bureau voor de Statistiek (2009), Gezondheid en zorg in ciffers 2009, Den Haag: CBS.

Czypionka, T., M. Kraus, G. Röhrling and H. Straka (2008), Case Management in Austria and Europe, Vienna: The Institute for Advanced Studies.

Czypionka, T. and G. Röhrling (2009), 'Analyse der Reformpool-Aktivität in Österreich: Wie viel Reform ist im Reformpool?', Health System Watch, II: 1-16.

Eichwalder, S. and M. Hofmarcher (2008), 'Failure to improve care outside hospitals', Health Policy Monitor, http://www.hpm.org/survey/at/a11/2 [22 April 2010]. 
Ettelt, S., E. Nolte, N. Mays, S. Thomson and M. McKee and International Healthcare Comparisons Network (2006), Health Care Outside Hospital. Accessing Generalist and Specialist Care in Eight Countries, Copenhagen: World Health Organization on behalf of the European Observatory on Health Systems and Policies.

Fullerton, B., E. Nolte and A. Erler (2011), 'Qualität der Versorgung chronisch Kranker in Deutschland', Zeitschrift für Evidenz, Fortbildung und Qualität im Gesundheitswesen, in press.

Glasby, J., H. Dickinson and E. Peck (2006), 'Guest editorial: partnership working in health and social care', Health and Social Care in the Community, 14: 373-374.

Habl, C. and F. Bachner (2010), Health Care in Austria, Vienna: Österreichisches Bundesinstitut für Gesundheitswesen.

Ham, C. (2003), 'Improving the performance of health services: the role of clinical leadership', Lancet, 361: 1978-1980.

Helderman, J.K., F.T. Schut, T.E.D. Van der Grinten and W.P.M.M. Van de Ven (2005), 'Market-oriented health care reforms and policy learning in the Netherlands', Journal of Health Politics, Policy and Law, 30: 189-209.

Hofmarcher, M. and B. Hawel (2010), 'Ambulatory care reforms fail to face the facts'?, Health Policy Monitor, http://hpm.org/survey/at/a15/1 [13 September 2010].

Hofmarcher, M.M., H. Oxley and E. Rusticelli (2007), Improved Health System Performance through Better Care Coordination, Paris: OECD.

Hofmarcher, M. and H.-M. Rack (2006), 'Austria: health system review', Health Systems in Transition, 8(3): 1-247.

Hofmarcher, M.M., G. Röhrling and D. Walch (2007), 'Integration of care - follow up', Health Policy Monitor, http://hpm.org/survey/at/b9/2 [13 September 2010].

Klein-Lankhorst, E. and C. Spreeuwenberg (2008), 'The Netherlands', in C. Knai, E. Nolte and M. McKee (eds), Managing Chronic Conditions - Experience in Eight Countries, Copenhagen: European Observatory on Health Systems and Policies.

Linden, B. (2000), The Birth of Integration, Explorative Studies on the Development and Implementation of Integrated Care in the Netherlands Dissertation. Utrecht: University of Utrecht.

Linder, R., S. Ahrens, D. Köppel, T. Heilmann and F. Verheyen (2011), 'The benefit and efficiency of the disease management program for type 2 diabetes', Deutsches Ärzteblatt International, 108: 155-162.

Miksch, A., G. Laux, D. ose, S. Joos, S. Campbell, B. Riens and J. Szecsenyi (2010), 'Is there a survival benefit within a German primary care-based disease management program?', The American Journal of Managed Care, 16: 49-54.

Nolte, E., C. Knai and M. McKee (eds) (2008), Managing Chronic Conditions: Experience in Eight Countries, Copenhagen: World Health Organization on behalf of the European Observatory on Health Systems and Policies.

Nolte, E. and M. McKee (eds) (2008a), Caring for People with Chronic Conditions: A Health System Perspective, Maidenhead: Open University Press.

Nolte, E. and M. McKee (2008b), 'Making It Happen', in E. Nolte and M. McKee (eds), Caring for People with Chronic Conditions: A Health System Perspective, Maidenhead: Open University Press, 222-244.

OECD (2010), OECD Health Data, Paris: OECD.

Ose, D., M. Wensing, S. Szecsenyi, S. Joos, K. Hermann and A. Miksch (2009), 'Impact of primary care-based disease management on the health-related quality of life in patients with type 2 diabetes and comorbidity', Diabetes Care, 32: 1594. 
Österreichische Diabetes Gesellschaft (2010), 'Presseinformation der ÖGD. Erfolgreiche 1. Zwischenbilanz für Diabetes Programm, Therapie aktiv"', http://www.oedg.org/pdf/ PA_10_04_DMP.pdf [25 May 2010].

Partnership Overweight Netherlands (2009), 'Tackling the problem of overweight and obesity: the Dutch approach', http://www.partnerschapovergewicht.nl/site_files/uploads/ RVWS020\%20Affiche\%20KCO-CO-PON.pdf [29 May 2011].

Pomerleau, J., C. Knai and K. Nolte (2008), 'The Burden of Chronic Disease in Europe', in E. Nolte and M. McKee (eds), Caring for People with Chronic Conditions: A Health System Perspective, Maidenhead: Open University Press, 15-42.

RAND Europe and London School of Hygiene\& Tropical Medicine (2011), Chronic Disease Management. An Overview of 13 Countries Unpublished report. Cambridge: RAND Europe.

Ruh, C., S. Winter, E. Zeiler and M. Robausch (2009), 'Evaluation des Reformpool-Projektes, Disease-Management-Programm Diabetes mellitus Typ 2 - Therapie Aktiv" in der Region Waldviertel', Soziale Sicherheit, May: 267-277.

Sachverständigenrat zur Begutachtung der Entwicklung im Gesundheitswesen (2009), Koordination und Integration - Gesundheitsversorgung in einer Gesellschaft des längeren Lebens, Bonn: Sachverständigenrat zur Begutachtung der Entwicklung im Gesundheitswesen.

Schäfer, I., C. Küver, B. Gedrose, F. Hoffmann, B. Russ-Thiel, H.P. Brose, H. van den Bussche and H. Kaduszkiewicz (2010a), 'The disease management program for type 2 diabetes in Germany enhances process quality of diabetes care - a follow-up survey of patient's experiences', BMC Health Services Research, 10: 55.

Schäfer, I., C. Küver, B. Gedrose, E.C. von Leitner, A. Treszl, K. Wegscheider, H. van den Bussche and H. Kaduszkiewicz (2010b), 'Selection effects may account for better outcomes of the German Disease Management Program for type 2 diabetes', BMC Health Services Research, 10: 351.

Schäfer, W., M. Kroneman, W.G.W. Boerma, M. van den Berg, G. Westert, W. Deville and R. van Ginneken (2010), 'The Netherlands: health system review', Health Systems in Transition, 12(1): 1-229.

Siering, U. (2008), ‘Germany', in E. Nolte, C. Knai and M. McKee (eds), Managing Chronic Conditions - Experience in Eight Countries, Copenhagen: World Health Organizaton on behalf of the European Observatory on Health Systems and Policies, 75-96.

Sönnichsen, A.C., H. Winkler, M. Flamm, S. Panisch, P. Kowatsch, G. Klima, B. Fürthauer and R. Weitgasser (2010), 'The effectiveness of the Austrian disease management programme for type 2 diabetes: a cluster-randomised controlled trial', BMC Family Practice, 11: 86.

Steuten, L.M.G., H.J.M. Vrijhoef, C. Spreeuwenberg and G.G. Van Merode (2002), 'Participation of general practitioners in disease management: experiences from the Netherlands', International Journal of Integrated Care, 2: 1-5.

Stock, S., A. Drabik, G. Büscher, C. Graf, W. Ullrich, A. Gerber, K.W. Lauterbach and M. Lüngen (2010), 'German diabetes management programs improve quality of care and curb costs', Health Affairs, 29: 2197-2205.

Struijs, J.N., J.T. van Til and C.A. Baan (2010), Experimenting with a Bundled Payment System for Diabetes Care in the Netherlands, Bilthoven: National Institute for Public Health and the Environment.

Therapie Aktiv Diabetes im Griff (2011), 'Umsetzungsstand in Österreich', http://diabetes. therapie-aktiv.at/portal27/portal/diabetesportal/channel_content/cmsWindow? action $=2 \&$ p_menuid=66241\&p_tabid=2 [8 February 2011]. 
TNS Opinion and Social (2007), Health in the European Union. Special Eurobarometer 272e, Brussels: European Commission.

Van Til, J.T., J.E. De Wildt and J.N. Struijs (2010), De organisatie van zorggroepen anno 2010. Huidige stand van zaken en de ontwikkelingen in de afgelopen jaren [The Organisation of Care Groups in 2010. Current State of Affairs and Developments Over the Past Years], Bilthoven: National Institute for Public Health and the Environment (RIVM).

Vrijhoef, H.J.M., C. Spreeuwenberg, I.M.J.G. Eijkelberg, B.H.R. Wolffenbuttel and G.G. van Merode (2001), 'Adoption of disease management model for diabetes in region of Maastricht', British Medical Journal, 323: 983-985.

Vrijhoef, H.J.M. (2010), 'Chronische zorg in Nederland anno 2010: leidt verandering tot verbetering?’, Forum, 2: 59-62. 